\title{
Mesenchymal stem cell-derived hepatocytes for functional liver replacement
}

\section{Bruno Christ ${ }^{1,2 *}$ and Peggy Stock ${ }^{1}$}

${ }^{1}$ Applied Molecular Hepatology Laboratory, Department of Visceral, Transplantation, Thoracic and Vascular Surgery, University Hospital Leipzig, Leipzig, Germany

${ }_{2}^{2}$ Translational Centre for Regenerative Medicine, Leipzig, Germany

\section{Edited by:}

Martin Johannes Hoogduijn, Erasmus

Medical Center, Netherlands

Reviewed by:

Anat R. Tambur, Northwestern University, USA

Reem Al Daccak, Institut National de Sante et de Recherche Medical,

France

\section{*Correspondence:}

Bruno Christ, Department of Visceral, Transplantation, Thoracic and Vascular Surgery, University Hospital of Leipzig, Liebigstraße 21, D-04103

Leipzig, Germany.

e-mail: bruno.christ@medizin.uni-

leipzig.de
Mesenchymal stem cells represent an alternate cell source to substitute for primary hepatocytes in hepatocyte transplantation because of their multiple differentiation potential and nearly unlimited availability. They may differentiate into hepatocyte-like cells in vitro and maintain specific hepatocyte functions also after transplantation into the regenerating livers of mice or rats both under injury and non-injury conditions. Depending on the underlying liver disease their mode of action is either to replace the diseased liver tissue or to support liver regeneration through their anti-inflammatory and anti-apoptotic as well as their pro-proliferative action.

\section{Keywords: cell transplantation, mesenchymal stem cells, liver, hepatocyte}

\section{WHY TALK ABOUT ALTERNATIVES?}

It could have been a good idea to replace diseased liver tissue by healthy hepatocytes in order to provide the metabolic power, which gets lost during liver damage from any kind of challenge viral, genetic, chemical intoxication, etc., (Muraca, 2011; Puppi et al., 2011; Hughes et al., 2012). This concept is based on the assumption that the hepatocyte represents the smallest functional unit of the liver executing all the single metabolic services as the liver does as a whole. Indeed, hepatocyte transplantation has been proven feasible in animal trials and turned out to promise an alternative to liver transplantation in clinical settings. Usually, in rodents cells are administered to the liver either via the splenic vein after injection into the spleen or via the portal vein. Cells then spread with the blood stream over the entire organ and enter the parenchyma after endothelial penetration. They integrate and proliferate and ideally take over the hepatocytes' metabolic functions in the long-term range. There is huge experience in hepatocyte transplantation available from animal trials comprising acute and chronic liver disease models. Provided that a mitotic challenge and a regenerative advantage is presented to the donor hepatocytes then significant or even nearly complete repopulation of the host liver might be achieved. Yet, without this the rate of repopulation is rather low ranging at about $1 \%$ (Santoni-Rugiu et al., 2005; Christ, 2006; Weber et al., 2009; Shafritz and Oertel, 2011). There is doubt whether this is sufficient to supply the metabolic capacity needed to overcome the malfunction of the damaged host liver in clinical applications. An estimate of $1-5 \%$ of repopulating hepatocytes has been considered to suffice for the correction of a genetic metabolic defect of the liver (Fox and Roy-Chowdhury, 2004a; Lee et al., 2004b). Patients suffering from the defect of UDP-glucoronosyltransferase (Crigler-Najjar-Syndrome; Fox et al., 1998) or of glucose-6-phosphatase (glycogen storage disease type Ia; Muraca et al., 2002) improved after receiving human hepatocyte transplants at least for a transient period of time. Thus, hepatocyte transplantation has also gained proof-of-concept in clinical trials, which is documented by more than 30 ongoing or published studies (Muraca, 2011; Christ and Brückner, 2012; Hughes et al., 2012). Yet, one problem seriously hampers clinical breakthrough of hepatocyte transplantation. There are $30 \%$ more patients on the waiting list for liver transplantation than actually receive the life-saving organ both in the United States $^{1}$ and in Europe ${ }^{2}$ indicating the scarcity of donor livers. It is self-evident that in this situation also livers to isolate primary hepatocytes for purposes of cell transplantation are scarce and, they are often marginal yielding hepatocytes of minor quality and insufficient quantity. Hence, even if hepatocyte transplantation turned out a versatile alternative to liver transplantation the shortage of donor livers prompted the search for novel cell resources to generate hepatocytes or hepatocyte-like cells. It might be assumed that the principles of hepatocyte transplantation are also valid for these "artificial hepatocytes" in terms of cell transplant quantity, site of application, mode of action, principles of tissue integration, and finally therapeutic support in the shortand long-term range. This approach sounds rather straightforward and therefore it is worthy to talk about alternatives, which would aid to provide surgical potential in order to manage the bottleneck of donor liver availability both for organ and hepatocyte transplantation.

\footnotetext{
${ }^{1}$ www.unos.org/

${ }^{2}$ http://www.eurotransplant.nl/
} 


\section{HEPATIC STEM CELLS ARE DOING THE JOB OF LIVER REGENERATION}

Tissue turnover is not the liver's most prominent quality under resting, i.e., healthy conditions. With only $0.01 \%$ hepatocytes undergoing mitosis the organ seems rather indolent without any provocation (Steiner et al., 1966; Koniaris et al., 2003). Yet, in case of liver damage accompanied by massive hepatocyte loss the organ displays a remarkable regenerative potential. After two third partial hepatectomy the liver mass is restored after only about 1-2 weeks in rodents. The regenerative process is tightly regulated by a plethora of cytokines, hormones, factors, and their interactions. The initial response is triggered by the liver-resident macrophages, the Kupffer cells, which engages the activation by tumor necrosis factor $\alpha$ (TNF- $\alpha)$, components of the complement system (C3a/5a), lymphotoxin, just to mention some of those best known until today. The Kupffer cells then secrete the pro-inflammatory cytokine IL-6, which targets the hepatocytes and activates the canonical IL-6-signaling pathway involving gp130-mediated dimerization of STAT3 and the downstream activation of IL- 6 target genes. This socalled priming phase initiates hepatocyte proliferation involving a second set of factors comprising hepatocyte growth factor (HGF) and epidermal growth factor (EGF) receptor ligand family such as transforming growth factor $\alpha$ (TGF- $\alpha$ ), heparin-binding EGF-like growth factor and amphiregulin. Hepatocyte proliferation continues until the original mass of the liver is restored (Fausto and Campbell, 2003; Michalopoulos, 2007, 2010; Riehle et al., 2011). Thus, liver regeneration after partial hepatectomy obviously does not involve liver stem cells. Yet, there is evidence that hepatocytes may not only generate hepatocytes but may also differentiate into other liver cell types such as biliary epithelial cells (Michalopoulos et al., 2005) or pancreatic cells (Horb et al., 2003; Burke et al., 2006). Hence, hepatocytes themselves fulfill the basic criteria of stem cells, the self-renewal and multiple differentiation potential giving rise to progeny of at least two different lineages.

The liver contains a parenchymal back-up compartment, which is activated under injury conditions preventing mature hepatocyte proliferation and/or causing hepatocyte replicative senescence. Experimentally, such situations may be provoked in rodents by feeding a choline-deficient diet in combination with the administration of acetylaminofluorene (AAF) or ethionine, by galactosamine or dipin combined with partial hepatectomy to mention a few (Koniaris et al., 2003; Santoni-Rugiu et al., 2005; Shafritz and Oertel, 2011). Liver progenitor cells - called oval cells in rodents emerge in the periportal areas of the liver lobule comprising the Canals of Hering, structural links between the terminal biliary branches and the periportal hepatocytes surrounding the proximal parts of the sinusoids. Under healthy conditions oval cells are rare and hardly detectable. It is widely agreed upon that the oval cells are the bipotent progeny of hepatic stem cells, of which their real nature and existence in the adult liver has still to be substantiated (Sell, 2001; Fausto, 2004; Kofman et al., 2005; Santoni-Rugiu et al., 2005; Oertel and Shafritz, 2008). But, due to similar marker gene expression patterns it has been proposed that there might exist a precursor/product relationship between the embryonic hepatoblasts and the oval cells (Fausto and Campbell, 2003). In humans hepatic progenitor cells, perhaps equivalent to the oval cells in rodents, appear in the pathophysiological situations of viral hepatitis, liver cancer and massive drug intoxication (Roskams et al., 2004, 2010). Injuries occurring under these conditions provoke so-called ductular reactions, of which the hallmark is the appearance of transit amplifying cells, the progeny of hepatic progenitor cells residing in the liver stem cell niche, the Canals of Hering (Roskams et al., 2004; Gouw et al., 2011). Hepatic progenitor cells may be identified based on the expression of cytokeratin 7 (CK7), epithelial cell adhesion molecule (EpCAM), neural adhesion molecule, and CD133 (Alison et al., 2009; Gouw et al., 2011; Rountree et al., 2012). The cells of the ductular reactions display an intermediate immunophenotype featuring both biliary and hepatocyte marker expression. There is emerging evidence that the etiology of the liver disease may imprint the phenotype of the cells of the ductular reaction indicating their bipotent differentiation capacity, but which may also be the result of stimulation of different hepatic stem cell niches or the differential activation of one and the same niche under different hepatic injury conditions (Van Den Heuvel et al., 2001; Spee et al., 2010; Turner et al., 2011). Indeed, active NOTCH signaling seems to specify cholangiocyte differentiation whereas this pathway must be shut off for hepatocyte differentiation, which, however, requires in addition active Wnt signaling (Spee et al., 2010; Nejak-Bowen and Monga, 2011; Boulter et al., 2012).

In recent times it became obvious that hepatic stem cells might also derive from extrahepatic sources such as the bone marrow. In the animal model of fumarylacetoacetate hydrolase (FAH) deficiency featuring human Tyrosinemia type I transplantation of hematopoietic stem cells (HSC) resulted in the rescue of the disease phenotype in the mouse liver due to the generation of HSCderived functional hepatocytes (Lagasse et al., 2000; Grompe, 2003; Wang et al., 2003a). Oval cells were also attributed to be of bone marrow origin (Petersen et al., 1999; Alison et al., 2000; Theise et al., 2000). Yet, not differentiation of the HSC into hepatocytes but rather fusion with host hepatocytes was the product of donor cell-derived hepatocytes (Petersen et al., 1999; Alison et al., 2000; Theise et al., 2000; Alvarez-Dolado et al., 2003; Vassilopoulos et al., 2003; Wang et al., 2003a,b; Camargo et al., 2004).

Besides HSC the bone marrow harbors mesenchymal stem cells (MSC), which are CD34- and CD45-negative indicating their non-hematopoietic nature. They feature multiple differentiation potential including lineage commitment into cells of all three germ layers (Pereira et al., 1995; Pittenger et al., 1999; Jiang et al., 2002). Their hepatocyte differentiation capacity in vitro and in vivo has been demonstrated and because of their easy availability and low ethical risks MSC have become an attractive cell source for clinical cell therapy approaches including cell therapy of liver diseases (see below).

There is great hope in induced pluripotent stem cells (iPS), which were generated first in mice from somatic cells complemented with the so-called pluripotency factors, Oct4, Sox2, Klf4, and c-Myc re-programming the cells into an embryonic stem celllike genotype (Takahashi and Yamanaka, 2006). One prominent feature of these cells is their pluripotent differentiation capability, which comprises differentiation into cells from the three germ layers such as cardiomyocytes, adipocytes, neurons, hematopoietic precursors, osteoclasts, pancreatic cells (for recent reviews cf.; Hanna et al., 2010; Okita and Yamanaka, 2011; Bilic and Belmonte, 
2012). Endodermal differentiation includes also hepatocyte differentiation (Yagi et al., 2009; Ghodsizadeh et al., 2010; Takayama et al., 2012). Introduction of the factors is achieved by viral, chemical, and DNA-mediated delivery. All of these methods raise safety concerns, which in addition to the tendency of the iPS to form teratoma, restrict the clinical use of these cells so far. However, first liver repopulation experiments in mice demonstrated the high regenerative potential of iPS (Espejel et al., 2010), which certainly opens a clinical perspective. This is highly relevant since application of cells of autologous origin back to the patient avoids the long-term risks associated with immunosuppression.

Thus, in summary liver regeneration might be accomplished by liver stem cells either of intrinsic origin or from extrahepatic sources like bone marrow (MSC) or any somatic cell. This clearly opens the perspective to generate "artificial hepatocytes" from stem cells for clinical hepatocyte transplantation (Fox and Roy-Chowdhury, 2004b).

\section{MESENCHYMAL STEM CELLS - THE PREMIUM LIVER CELLS?}

One feasible alternative to human adult hepatocytes is the use of hepatocytes derived from human MSC. Experiments in rats (Wang et al., 2004; Lange et al., 2005), mice (Jiang et al., 2002), and humans (Schwartz et al., 2002; Lee et al., 2004a; Hong et al., 2005; Seo et al., 2005; Taléns-Visconti et al., 2006; Aurich et al., 2007; Banas et al., 2007) confirmed the in vitro differentiation potential of MSC from prominent sources like bone marrow or adipose tissue. In the following we will reference some of the studies using MSC in order to indicate their versatile application in animal models of different liver diseases.

Cultured bone marrow-derived MSC from male albino rats were infused into the tail vein of female rats treated with carbontetrachloride $\left(\mathrm{CCl}_{4}\right)$ to induce liver fibrosis. Y chromosome-positive donor cells were found in the female host liver exhibiting reduced collagen depositions and improved liver functions (Abdel Aziz et al., 2007). Attenuation of $\mathrm{CCl}_{4}$-induced liver fibrosis was also demonstrated using hepatocyte-like cells differentiated from bone marrow-derived MSC in the rat (Oyagi et al., 2006). Undifferentiated human bone marrow-derived MSC attenuated acute liver injury induced by allyl alcohol in Sprague Dawley rats (Sato et al., 2005). Hepatic integration and function of human adipose tissuederived MSC pre-differentiated into hepatocyte-like cells prior to transplantation was shown both in $\mathrm{CCl}_{4}$-treated mice (Seo et al., 2005; Banas et al., 2007) and rats after partial hepatectomy (Sgodda et al., 2007). Not surprisingly, hepatocyte pre-differentiated MSC were more effective as compared to their undifferentiated precursors. In the hepatectomized SCID mouse model bone marrowderived MSC pre-differentiated into hepatocyte-like cells in vitro xenografted to the mouse livers and expressed hepatocyte markers such as albumin and CK18 (Lysy et al., 2008; Aurich et al., 2009). MSCs engrafted predominantly in the periportal portion of the liver lobule displaying hepatocyte-specific features like glycogen storage and expression of phosphoenolpyruvate carboxykinase, connexin32, albumin, and the human hepatocyte-specific antigen HepPar1 (Aurich et al., 2007).

In summary, irrespective of the site of application, i.e., systemic infusion, intrahepatic injection, intrasplenic delivery, or portal vein infusion MSC were found in the liver of the host animal forming clusters of donor cells. These cells were functional in terms of expression of specific markers and secretion of albumin. In the case of acute and chronic liver architecture deterioration MSC improved the disease. Both undifferentiated and hepatocyte-differentiated MSC integrate functionally into the host liver but at significant higher rates using differentiated cells. Facing the fact that functional characterization of MSC-derived hepatocyte-like cells after transplantation is fragmentary at best, is it then reasonable to use MSC in clinical applications?

\section{MSC FOR HEPATIC REPAIR - SAFE OR NOT SAFE?}

In the following section animal studies will be exemplified to delineate critical aspects of potential safety concerns before translation of MSC-based hepatocyte transplantation into the clinics. These include site of administration, distribution, bioavailability, elimination, and tumorigenicity.

MSC display migratory competence. After systemic application they migrate to inflammatory sites attracted by chemokines liberated from the regions of tissue injury. Intrasplenic and hepatic injection have been chosen as the sites primarily used for transplantation of adult hepatocytes. It may be anticipated that a portion of injected cells resides in the spleen, which provides an acceptable tissue environment for adult hepatocytes to survive, proliferate, and execute hepatocyte-specific functions without systemic side effects (Kusano and Mito, 1982). Very likely the mechansims of hepatic integration of stem cell-derived hepatocytes is similar or even equal to that of adult hepatocytes as discussed above. Transplanted hepatocytes mainly engraft in the periportal regions of the liver lobule and acquire the gene expression pattern of periportal hepatocytes (Aurich et al., 2005). However, shifting transplanted hepatocytes into the perivenous areas by treatment with carbontetrachloride resulted in the change from a periportal to a perivenous hepatocyte expression pattern in these cells. This indicates that the hepatic microenvironment governs the differentiation state of transplanted cells directing position-specific gene expression (Gupta et al., 1999; Koenig et al., 2007). Intraportal infusion of hepatocytes resulted also in entrapment of cells passaged through the liver into the lung parenchyma of New Zealand rabbits (Schneider et al., 2003). Yet, virtually all hepatocytes were cleared from the pulmonary capillaries within $24 \mathrm{~h}$ (Rajvanshi et al., 1999; Schneider et al., 2003). Hepatic engraftment after transplantation of human bone marrow-derived MSC into the spleen or the liver was similar in SCID mice (Lysy et al., 2008). As mentioned above MSC-derived hepatocyte-like cells both after intrasplenic and portal administration were found in the periportal areas of the liver lobule where they featured typical characteristics of periportal hepatocytes 10 weeks post-transplant (Aurich et al., 2007, 2009).

Principally, undifferentiated MSC may contribute to the formation of most if not all somatic cell types. This has been confirmed by injecting mouse multipotent adult progenitor cells into mouse blastocysts. Donor cells were found in hematopoietic organs and in the epithelia of the lung, liver, and gut (Jiang et al., 2002). Injection of undifferentiated murine bone marrow-derived MSC into the tail vein of NOD/SCID mice resulted in engraftment of donor cells into gastrointestinal organs but also in the lung and skin (AnjosAfonso et al., 2004), a result, which was also demonstrated after 
intravenous application of undifferentiated bone marrow MSC into baboons (Devine et al., 2003). Taking advantage of the permissive milieu of tissues and organs during organogenesis, fetal sheep were transplanted i.p. with human bone marrow-derived MSC, which integrated and differentiated into blood, liver, and skin cells (Almeida-Porada and Zanjani, 2004). Intrahepatic versus intraperitoneal injection of human MSC improved the percentage amount of human hepatocytes in sheep livers by fivefold (Chamberlain et al., 2007). It may be concluded that under minimal injury conditions as in the models described here MSC may give rise to cell types of different tissues and organs but that hepatic injury leads primarily to engraftment in the liver. Hence, it is very likely that MSC, both native and hepatocyte-differentiated home to the liver without significant extrahepatic tissue colonization.

There is evidence that MSC might contribute to extrahepatic manifestation of cancer or even liver cancer. It is a generally accepted concept that mature differentiated cells in a tissue originate from multipotent stem cells via tissue-specific stem and/or progenitor cell differentiation. Tumorigenic transformation at each step of this one-way lineage leads to loss of the differentiated phenotype and may give rise to a putative cancer (stem) cell developing into tumors of the respective tissues (cf.; MartínezCliment et al., 2006; Polyak and Hahn, 2006; Ailles and Weissman, 2007; Wu, 2008; for recent reviews). Common properties of both tissue-specific stem cells and tumor (stem) cells are their potential of self-renewal, differentiation, and gene expression signatures supporting the abovementioned concept. Thus, any mutational event given will cause expansion of stem/progenitor cells normally quiescent in the healthy tissue thereby increasing their propensity to tumor development. The tumor stroma contains mesenchymal cells (MTC) with an invasive phenotype contributing to neoangiogenesis, which they share with MSC. Thus, similar morphological and immunological features, as well as the expression of a common set of stemness signature genes might indicate the risk of the therapeutic use of MSCs under tumor-promoting conditions (Studeny et al., 2004; Galie et al., 2008). There is controversy whether or not somatic stem cells are involved in hepatocarcinogenesis (Wu and Yu, 2007). It is known that MSC tend to malignant transformation in culture after extended expansion. However, in a transgenic mouse model of hepatocellular cancer (HCC) induced by diethylnitrosamine and phenobarbital bone marrow cells did not progress to HCC (Ishikawa et al., 2004). Similar results were found in non-transgenic Balb/c mice after chemical induction of HCC by diethylnitrosamine (Zheng and Liang, 2008). In the Lewis rat, bone marrow-derived stem cells were recruited to the liver after feeding a choline-deficient diet, fused with hepatic oval cells but did not contribute to pre-neoplastic nodule formation (Kubota et al., 2008). Numerous studies have since shown hepatogenic differentiation from both hematopoietic and MSC without cellular fusion in a variety of different animal disease models (Ishikawa et al., 2003; Newsome et al., 2003; Jang et al., 2004; Sato et al., 2005). Thus, even under conditions favoring tumorigenesis in the liver, no contribution of MSC to tumor formation in the liver has been reported so far whatever site of application or carcinogen was being used. Most of the studies described above applied MSC not pre-differentiated into hepatocyte-like cells prior to hepatic transplantation. In a murine melanoma model the impact of differentiated and undifferentiated MSC on tumor growth and metastasis was investigated. Ectopic administration of allogeneic MSC showed that MSC after chondrogenic differentiation did not display migratory activity and reduced the promotion of tumor growth while undifferentiated MSC migrated to the site of the tumor and favored tumor growth and metastasis (Akay et al., 2010). It seems to be a general feature of undifferentiated MSC to be recruited to the tumor stroma as shown previously in a culture model of human glioblastoma (Birnbaum et al., 2007). Nevertheless it cannot be excluded that MSC promote tumor growth indirectly due to their propensity to form progenitor cells of tumor vessels exemplifying the pro-angiogenic properties of MSC (Kinnaird et al., 2004) and/or stromal-fibroblast like cells thus impacting the tumor stroma and supporting tumor growth (Huss et al., 2004; Feng and Chen, 2009; Mishra et al., 2009; Zischek et al., 2009). There is also evidence that MSC by producing antiinflammatory molecules reduce pancreatic tumor growth (Zischek et al., 2009). On the other hand the immunosuppressive features of undifferentiated MSC might favor tumor growth and metastasis as shown in rodent animal models (Djouad et al., 2003; Zhu et al., 2006; Krampera et al., 2007).

Thus, the current knowledge does not allow for the safe use of MSC in clinical settings at least in terms of tumorigenicity. Therefore, investigations in large animal models of liver diseases like in the pig are appreciated to study the behavior of MSC under the given environment produced by the specific disease. In recent times pig models for isolation and transplantation of MSC became available (Casado et al., 2012), which now allow for the evaluation of both the therapeutic and the potential side effects of MSC as close as possible to the human situation (Shi et al., 2010; Groth et al., 2012; Li et al., 2012).

\section{MSC FOR HEPATIC REPAIR -WHICH MODE OF ACTION DO WE NEED?}

Due to their specific properties like low immunogenicity and promotion of anti-inflammatory responses MSC act immunomodulatory (Djouad et al., 2003; Krampera et al., 2007; Newman et al., 2009). The application of allogeneic MSC does not provoke an immune response in vitro or in vivo. This might be partially due to the expression of intermediate levels of HLA class I antigens and lack of expression of HLA class II antigens on the cell surface (Di Nicola et al., 2002; Le Blanc et al., 2003; Klyushnenkova et al., 2005; Sotiropoulou et al., 2006). The MSC-mediated immune modulation mechanistically varies depending on the immune cell type affected (Meisel et al., 2004; Aggarwal and Pittenger, 2005; Nasef et al., 2007; Feng and Chen, 2009; Siegel et al., 2009). MSC interact with dendritic cells (DC) as well as with T-cells, B-lymphocytes, and with NK cells (Aggarwal and Pittenger, 2005; Nauta and Fibbe, 2007; Noel et al., 2007; Stagg and Galipeau, 2007). They modulate generation, activation as well as function of DC at different levels of differentiation (Jiang et al., 2005; Nauta et al., 2006; Hematti, 2008). They inhibit the maturation and migration of DC to the lymph nodes and the secretion of TNF- $\alpha$ by DC (Krampera et al., 2006; Spaggiari et al., 2006; Nasef et al., 2007; Ramasamy et al., 2007).

Recent studies identified two different functional types of MSC. Depending on the prevailing conditions immunosuppressive MSC 
or immunogenic MSC may be distinguished. In the presence of pro-inflammatory cytokines like TNF- $\alpha$ and interferon-gamma (IFN- $\gamma$ ) the immunosuppressive phenotype of MSC is favored. If anti-inflammatory cytokines like IL-10 are predominant the suppressive effect of MSC is abrogated (Renner et al., 2009). Depending on the level of IFN- $\gamma$ MSC furthermore exhibit antigenpresenting properties (Chan et al., 2006). After chondrogenic differentiation the immunological properties of xenogeneic MSC changed. Differentiated MSC promoted human DC maturation by stimulation of CD38 expression on the DC and upregulation of B7 expression on MSC. Yet, osteogenic, chondrogenic and adipogenic differentiation did not alter the immunosuppressive properties of MSC (Chen et al., 2007), which supported the conclusion that MSC, undifferentiated, or differentiated, may be accepted even by HLA-incompatible patients.

MSC attenuate secretion of major pro-inflammatory cytokines like TNF- $\alpha$ and IFN- $\gamma$ and thus reverse tissue inflammation, which is supported by an increased expression of the immunosuppressive cytokines IL-10 and TGF- $\beta$ secreted by the MSC (Krampera et al., 2006; Ryan et al., 2007; Zheng et al., 2008). Taken together this would explain the anti-inflammatory features of MSC (Di Nicola et al., 2002; Aggarwal and Pittenger, 2005; Chabannes et al., 2007; Feng and Chen, 2009; Kode et al., 2009; Newman et al., 2009; Mao et al., 2010). Immunosuppressive and anti-inflammatory effects of MSC may be mediated on the molecular level by heme oxygenase (HO-1) and iNOS (Munn et al., 1998), indoleamine 2,3dioxygenase (IDO) preventing the T-cell response through tryptophan depletion (Aggarwal and Pittenger, 2005) or prostaglandin E2 (PGE 2 ; Bartholomew et al., 2002; Aggarwal and Pittenger, 2005; Beyth et al., 2005; Le Blanc and Ringden, 2005; Yanez et al., 2006; Nasef et al., 2007; Hematti, 2008). So far major attempts are under way to apply MSC for the prevention of Graft versus Host Disease (GVHD), rejection of organ transplants and for modulation of inflammation in general.

It may be concluded that MSC may play a pleiotropic role impacting a given disease by a specified mode of action, which is triggered by the diseased tissue environment. This includes tissue regeneration through substitution of the tissue lesion by functional cells differentiated from the MSC but also modulation of an inflammatory tissue environment thus improving or stimulating self-regeneration of the affected tissue. These pleiotropic mode of action is highly appreciated to treat liver diseases of different etiology. Acute or chronic liver injuries require the down-regulation of inflammatory processes in order to prevent progressing tissue damage whereas ample liver resection due to liver cancer might require substitution of functional loss. Hence, in the one case undifferentiated MSC might represent the cell source of choice while in the latter hepatocyte-differentiated MSC might be appreciated.

\section{WHAT TO DO NEXT?}

It must be anticipated that nearly all tissues harbor MSC, which upon tissue injury proliferate and differentiate into the cells of the tissue of origin to replace and functionally regenerate the injured tissue regions. Recently, MSC-like cells have even been isolated from adult human liver (Najimi et al., 2007; Covas et al., 2008) and liver grafts (Pan et al., 2011) suggesting that these cells might contribute to tissue repair after hepatic injury. So why not use MSC for allogeneic stem cell transplantation in liver diseases? As outlined above this concept has widely been proven in animal models of a great variety of different liver diseases, and indeed, finds increasing interest to progress into clinical translation. Liver cirrhosis is characterized by the irreversible deterioration of the liver's architecture resulting in the formation of regenerative nodules, which are separated by fibrotic septae. It may progress to liver cancer and/or liver failure with a very high incidence of mortality. MSC have been shown to ameliorate liver fibrosis in mice and rats, which was likely due to the reduction of collagen synthesis and the induction of expression of metalloproteinases, the major players in matrix degradation and remodeling (Parekkadan et al., 2007; Banas et al., 2008; Tsai et al., 2009). Acute liver failure is a highly inflammatory response of the liver to exogenous toxic insults, which is characterized by parenchymal dysfunction leading to systemic organ failures due to the lack of metabolic homeostasis normally provided by the healthy liver. The disease requires intensive care and like liver failure due to chronic dysfunction bears a high risk of mortality (Ostapowicz and Lee, 2000; Gill and Sterling, 2001; Rahman and Hodgson, 2001; O'Grady, 2005). Taking advantage of the anti-inflammatory, anti-apoptotic, and proproliferative features of MSC it has been shown in animal models that the cells attenuated acute liver failure by inhibition of inflammatory infiltration, reducing the rate of cell death, by increasing tissue recovery through stimulation of hepatocyte proliferation, and finally by augmenting survival rate (Parekkadan et al., 2007; van Poll et al., 2008; Zagoura et al., 2012). These encouraging results from animal studies prompted clinical application of MSC in chronic and acute liver failure ${ }^{3}$. However, so far there is only limited information available on the clinical outcome. In patients suffering from decompensated liver cirrhosis treatment with umbilical cord-derived MSC reduced ascites volume and improved liver function in the short-term range (Kharaziha et al., 2009; Zhang et al., 2012) and patients with end-stage liver failure improved in terms of ascites volume reduction and improvement in Child score after autologous bone marrow-derived MSC transplantation (Amer et al., 2011). These phase I/II clinical trials demonstrated safety of hepatic MSC transplantation at least under these indications but efficacy still awaits confirmation. Even if some clinical parameters might improve, the fate and long-term survival of the transplanted cells in the host liver, their mode of action, and finally safety in the long-term range have to be demonstrated.

\section{CONCLUSION}

It is likely that depending on the etiology and pathophysiology of the liver disease to be treated MSC act differently according to their pleiotropic spectrum of action. Thus, the anti-inflammatory, anti-apoptotic, and pro-proliferative features of MSC might be favorable in cases of chronic inflammatory liver diseases but in addition a functional tissue replacement is warranted in cases where massive tissue loss has to be substituted to provide sufficient metabolic capacity like in acute liver failure and huge liver resections. Therefore, it is necessary to understand the impact of

\footnotetext{
${ }^{3}$ http://clinicaltrials.gov
} 
MSC both on the molecular and cellular level and their interactions with the host liver tissue under a given microenvironment as created by the diseased liver. It might also be thought to use MSC in combination with primary human hepatocytes to either support hepatocyte function and moreover to minimize immunological rejection of the transplant in the short-term range taking advantage of the immunosuppressive features of

\section{REFERENCES}

Abdel Aziz, M. T., Atta, H. M., Mahfouz, S., Fouad, H. H., Roshdy, N. K., Ahmed, H. H., Rashed, L. A., Sabry, D., Hassouna, A. A., and Hasan, N. M. (2007). Therapeutic potential of bone marrow-derived mesenchymal stem cells on experimental liver fibrosis. Clin. Biochem. 40, 893-899.

Aggarwal, S., and Pittenger, M. F. (2005). Human mesenchymal stem cells modulate allogeneic immune cell responses. Blood 105, 1815-1822.

Ailles, L. E., and Weissman, I. L. (2007). Cancer stem cells in solid tumors. Curr. Opin. Biotechnol. 18, 460-466.

Akay, I., Oxmann, D., Helfenstein, A., Mentlein, R., Schünke, M., Hassenpflug, J., and Kurz, B. (2010). Tumor risk by tissue engineering: cartilaginous differentiation of mesenchymal stem cells reduces tumor growth. Osteoarthr. Cartil. 18, 389-396.

Alison, M., Islam, S., and Lim, S. (2009). Stem cells in liver regeneration, fibrosis and cancer: the good, the bad and the ugly. J. Pathol. 217, 282-298.

Alison, M. R., Poulsom, R., Jeffery, R., Dhillon, A. P., Quaglia, A., Jacob, J., Novelli, M., Prentice, G., Williamson, J., and Wright, N. A. (2000). Hepatocytes from nonhepatic adult stem cells. Nature 406, 257.

Almeida-Porada, G., and Zanjani, E. D. (2004). A large animal noninjury model for study of human stem cell plasticity. Blood Cells Mol. Dis. 32, 77-81.

Alvarez-Dolado, M., Pardal, R., GarciaVerdugo, J. M., Fike, J. R., Lee, H. O., Pfeffer, K., Lois, C., Morrison, S. J., and Alvarez-Buylla, A. (2003). Fusion of bone-marrowderived cells with Purkinje neurons, cardiomyocytes and hepatocytes. Nature 425, 968-973.

Amer, M. -. E. M., El-Sayed, S. Z., El-Kheir, W. A., Gabr, H., Gomaa, A. A., El-Noomani, N., and Hegazy, M. (2011). Clinical and laboratory evaluation of patients with endstage liver cell failure injected with bone marrow-derived hepatocytelike cells. Eur. J. Gastroenterol. Hepatol. 23, 936-941.
Anjos-Afonso, F., Siapati, E. K., and Bonnet, D. (2004). In vivo contribution of murine mesenchymal stem cells into multiple cell-types under minimal damage conditions. J. Cell. Sci. 117, 5655-5664.

Aurich, H., König, S., Schneider, C., Walldorf, J., Krause, P., Fleig, W. E., and Christ, B. (2005). Functional characterization of serum-free cultured rat hepatocytes for downstream transplantation applications. Cell Transplant. 14, 497-506.

Aurich, H., Sgodda, M., Kaltwasser, P., Vetter, M., Weise, A., Liehr, T., Brulport, M., Hengstler, J. G., Dollinger, M. M., Fleig, W. E., and Christ, B. (2009). Hepatocyte differentiation of mesenchymal stem cells from human adipose tissue in vitro promotes hepatic integration in vivo. Gut 58, 570-581.

Aurich, I., Mueller, L. P., Aurich, H., Luetzkendorf, J., Tisljar, K., Dollinger, M. M., Schormann, W., Walldorf, J., Hengstler, J. G., Fleig, W. E., and Christ, B. (2007). Functional integration of hepatocytes derived from human mesenchymal stem cells into mouse livers. Gut 56, 405-415.

Banas, A., Teratani, T., Yamamoto, Y., Tokuhara, M., Takeshita, F., Osaki, M., Kawamata, M., Kato, T., Okochi, H., Ochiya, T. (2008). IFATS series: in vivo therapeutic potential of human adipose tissue mesenchymal stem cells (atmscs) after transplantation into mice with liver injury. Stem Cells 26, 2705-2712.

Banas, A., Teratani, T., Yamamoto, Y., Tokuhara, M., Takeshita, F., Quinn, G., Okochi, H., and Ochiya, T. enchymal stem cells as a source of human hepatocytes. Hepatology 46, 219-228.

Bartholomew, A., Sturgeon, C., Siatskas, M., Ferrer, K., McIntosh, K., Patil, S., Hardy, W., Devine, S., Ucker, D., Deans, R., Moseley, A., and Hoffman, R. (2002). Mesenchymal stem cells suppress lymphocyte proliferation in vitro and prolong skin graft survival in vivo. Exp. Hematol. 30, 42-48. (2007). Adipose tissue-derived mes-

MSC (Stutchfield et al., 2010). This could help to bridge the patient to liver transplantation and even through the critical phase of acute liver failure until the host liver recovers from the acute insult. This is of high interest because this setting would enable allogeneic hepatocyte transplantation avoiding longterm immunosuppression with all the known undesired adverse effects.

Beyth, S., Borovsky, Z., Mevorach, D., Liebergall, M., Gazit, Z., Aslan, H., Galun, E., and Rachmilewitz, J. (2005). Human mesenchymal stem cells alter antigen-presenting cell maturation and induce T-cell unresponsiveness. Blood 105, 2214-2219.

Bilic, J., and Belmonte, J. C. I. (2012). Concise review: induced pluripotent stem cells versus embryonic stem cells: close enough or yet too far apart? Stem Cells 30, 33-41.

Birnbaum, T., Roider, J., Schankin, C. J., Padovan, C. S., Schichor, C., Goldbrunner, R., and A, S. (2007). Malignant gliomas actively recruit bone marrow stromal cells by secreting angiogenic cytokines. J. Neurooncol. 83, 241-247.

Boulter, L., Govaere, O., Bird, T. G., Radulescu, S., Ramachandran, P., Pellicoro, A., Ridgway, R. A., Seo, S. S., Spee, B., Van Rooijen, N., Sansom, O. J., Iredale, J. P., Lowell, S., Roskams, T., and Forbes, S. J. (2012). Macrophage-derived wnt opposes notch signaling to specify hepatic progenitor cell fate in chronic liver disease. Nat. Med. 18, 572-579.

Burke, Z. D., Shen, C. N., Ralphs, K. L. and Tosh, D. (2006). Characterization of liver function in transdifferentiated hepatocytes. J. Cell. Physiol. 206, 147-159.

Camargo, F. D., Finegold, M., and Goodell, M. A. (2004). Hematopoietic myelomonocytic cells are the major source of hepatocyte fusion partners. J. Clin. Invest. 113, 1266-1270.

Casado, J. G., Gomez-Mauricio, G., Alvarez, V., Mijares, J., Tarazona, R., Bernad, A., and SanchezMargallo, F. M. (2012). Comparative phenotypic and molecular characterization of porcine mesenchymal stem cells from different sources for translational studies in a large animal model. Vet. Immunol. Immunopathol. 147, 104-112.

Chabannes, D., Hill, M., Merieau, E., Rossignol, J., Brion, R., Soulillou, J. P., Anegon, I., and Cuturi, M. C. (2007). A role for heme oxygenase1 in the immunosuppressive effect of adult rat and human mesenchymal stem cells. Blood 110, 3691-3694.
Chamberlain, J., Yamagami, T., Colletti, E., Theise, N. D., Desai, J., Frias, A., Pixley, J., Zanjani, E. D., Porada, C. D., and Almeida-Porada, G. (2007). Efficient generation of human hepatocytes by the intrahepatic delivery of clonal human mesenchymal stem cells in fetal sheep. Hepatology 46, 1935-1945.

Chan, J. L., Tang, K. C., Patel, A. P., Bonilla, L. M., Pierobon, N., Ponzio, N. M., and Rameshwar, P. (2006). Antigen-presenting property of mesenchymal stem cells occurs during a narrow window at low levels of interferon-gamma. Blood 107, 4817-4824.

Chen, X., McClurg, A., Zhou, G.Q., McCaigue, M., Armstrong, M. A., and Li, G. (2007). Chondrogenic differentiation alters the immunosuppressive property of bone marrow-derived mesenchymal stem cells, and the effect is partially due to the upregulated expression of B7 molecules. Stem Cells 25, 364-370.

Christ, B. (2006). "Latest experimental models in hepatocyte transplantation," in Artificial Liver Support, Series: Falk Symposium, Vol. 145,ed. D. Henne-Bruns, K. Buttenschön, M. Fuchs, and A. Lohse (New York: Springer), 79-90.

Christ, B., and Brückner, S. (2012) Rodent animal models for surrogate analysis of cell therapy in acute liver failure. Front. Physiol. 3:78. doi:10.3389/fphys.2012.00078

Covas, D. T., Panepucci, R. A., Fontes, A. M., Silva, W. A. Jr, Orellana, M. D., Freitas, M. C., Neder, L., Santos, A. R., Peres, L. C., Jamur, M. C., Zago, M. A. (2008). Multipotent mesenchymal stromal cells obtained from diverse human tissues share functional properties and gene-expression profile with CD146 + perivascular cells and fibroblasts. Exp. Hematol. 36, 642-654.

Devine, S. M., Cobbs, C., Jennings, M., Bartholomew, A., and Hoffman, R. (2003). Mesenchymal stem cells distribute to a wide range of tissues following systemic infusion into nonhuman primates. Blood 101, 2999-3001. 
Di Nicola, M., Carlo-Stella, C., Magni, M., Milanesi, M., Longoni, P. D., Matteucci, P., Grisanti, S., and Gianni, A. M. (2002). Human bone marrow stromal cells suppress $\mathrm{T}$ lymphocyte proliferation induced by cellular or nonspecific mitogenic stimuli. Blood 99, 3838-3843.

Djouad, F., Plence, P., Bony, C., Tropel, P., Apparailly, F., Sany, J., Noel, D., and Jorgensen, C. (2003). Immunosuppressive effect of mesenchymal stem cells favors tumor growth in allogeneic animals. Blood 102, 3837-3844.

Espejel, S., Roll, G. R., McLaughlin, K. J., Lee, A. Y., Zhang, J. Y., Laird, D. J., Okita, K., Yamanaka, S., and Willenbring, H. (2010). Induced pluripotent stem cell-derived hepatocytes have the functional and proliferative capabilities needed for liver regeneration in mice. J. Clin. Invest. 120, 3120-3126.

Fausto, N. (2004). Liver regeneration and repair: hepatocytes, progenitor cells, and stem cells. Hepatology 39, 1477-1487.

Fausto, N., and Campbell, J. S. (2003). The role of hepatocytes and oval cells in liver regeneration and repopulation. Mech. Dev. 120, 117-130.

Feng, B., and Chen, L. (2009). Review of mesenchymal stem cells and tumors: executioner or coconspirator? Cancer Biother. Radiopharm. 24, 717-721.

Fox, I. J., Chowdhury, J. R., Kaufman, S. S., Goertzen, T. C., Chowdhury, N. R., Warkentin, P. I., Dorko, K., Sauter, B. V., and Strom, S. C. (1998). Treatment of the Crigler-Najjar syndrome type I with hepatocyte transplantation. N. Engl. J. Med. 338, 1422-1426.

Fox, I. J., and Roy-Chowdhury, J. (2004a). Hepatocyte transplantation. Am. J. Transplant. 4(Suppl. 6), 7-13.

Fox, I. J., and Roy-Chowdhury, J. (2004b). Hepatocyte transplantation. J. Hepatol. 40, 878-886.

Galie, M., Konstantinidou, G., Peroni, D., Scambi, I., Marchini, C., Lisi, V., Krampera, M., Magnani, P., Merigo, F., Montani, M., Boschi, F., Marzola, P., Orrù, R., Farace, P., Sbarbati, A., and Amici, A. (2008). Mesenchymal stem cells share molecular signature with mesenchymal tumor cells and favor early tumor growth in syngeneic mice. Oncogene 27, 2542 2551.

Ghodsizadeh, A., Taei, A., Totonchi, M., Seifinejad, A., Gourabi, H., Pournasr, B., Aghdami, N., Malekzadeh, R., Almadani, N., Salekdeh, G. H., and Baharvand, H. (2010). Generation of liver disease-specific induced pluripotent stem cells along with efficient differentiation to functional hepatocyte-like cells. Stem Cell Rev. 6, 622-632.

Gill, R. Q., and Sterling, R. K. (2001). Acute liver failure. J. Clin. Gastroenterol. 33, 191-198.

Gouw, A. S. H., Clouston, A. D., and Theise, N. D. (2011). Ductular reactions in human liver: diversity at the interface. Hepatology 54, 1853-1863.

Grompe, M. (2003). The role of bone marrow stem cells in liver regeneration. Semin. Liver Dis. 23, 363-372.

Groth, A., Ottinger, S., Kleist, C., Mohr, E., Golriz, M., Schultze, D., Bruns, H., Mehrabi, A., Schemmer, P., Büchler, M. W., and Herr, I. (2012). Evaluation of porcine mesenchymal stem cells for therapeutic use in human liver cancer. Int. J. Oncol. 40, 391-401.

Gupta, S., Rajvanshi, P., Sokhi, R. P., Vaidya, S., Irani, A. N., and Gorla, G. R. (1999). Position-specific gene expression in the liver lobule is directed by the microenvironment and not by the previous cell differentiation state. J. Biol. Chem. 274, 2157-2165.

Hanna, J. H., Saha, K., and Jaenisch, R. (2010). Pluripotency and cellular reprogramming: facts, hypotheses, unresolved issues. Cell 143, 508-525.

Hematti, P. (2008). Role of mesenchymal stromal cells in solid organ transplantation. Transplant. Rev. (Orlando) 22, 262-273.

Hong, S. H., Gang, E. J., Jeong, J. A., Ahn, C., Hwang, S. H., Yang, I. H., Park, H. K., Han, H., and Kim, H. (2005). In vitro differentiation of human umbilical cord blood-derived mesenchymal stem cells into hepatocytelike cells. Biochem. Biophys. Res. Commun. 330, 1153-1161.

Horb, M. E., Shen, C.-N., Tosh, D., and Slack, J. M. W. (2003). Experimental conversion of liver to pancreas. Curr. Biol. 13, 105-115.

Hughes, R. D., Mitry, R. R., and Dhawan, A. (2012). Current status of hepatocyte transplantation. Transplantation 93, 342-347.

Huss, R., Heil, M., Moosmann, S., Ziegelhoeffer, T., Sagebiel, S., Seliger, C., Kinston, S., and Gottgens, B. (2004). Improved arteriogenesis with simultaneous skeletal muscle repair in ischemic tissue by SCL+ multipotent adult progenitor cell clones from peripheral blood. J. Vasc. Res. 41, 422-431.

Ishikawa, F., Drake, C. J., Yang, S., Fleming, P., Minamiguchi, H., Visconti, R. P., Crosby, C. V., Argraves, W. S., Harada, M., Key, L. L. Jr., Livingston,
A. G., Wingard, J. R., and Ogawa, M. (2003). Transplanted human cord blood cells give rise to hepatocytes in engrafted mice. Ann. N. Y. Acad. Sci. 996, 174-185.

Ishikawa, H., Nakao, K., Matsumoto, K., Nishimura, D., Ichikawa, T., Hamasaki, K., and Eguchi, K. (2004). Bone marrow engraftment in a rodent model of chemical carcinogenesis but no role in the histogenesis of hepatocellular carcinoma. Gut 53, 884-889.

Jang, Y. Y., Collector, M. I., Baylin, S. B., Diehl, A. M., and Sharkis, S. J. (2004). Hematopoietic stem cells convert into liver cells within days without fusion. Nat. Cell. Biol. 6, 532-539.

Jiang, X. X., Zhang, Y., Liu, B., Zhang, S. X., Wu, Y., Yu, X. D., and Mao, N. (2005). Human mesenchymal stem cells inhibit differentiation and function of monocytederived dendritic cells. Blood 105 4120-4126.

Jiang, Y., Jahagirdar, B. N., Reinhardt, R. L., Schwartz, R. E., Keene, C. D., Ortiz-Gonzalez, X. R., Reyes, M., Lenvik, T., Lund, T., Blackstad, M., Du, J., Aldrich, S., Lisberg, A., Low, W. C., Largaespada, D. A., and Verfaillie, C. M. (2002). Pluripotency of mesenchymal stem cells derived from adult marrow. Nature 418, 41-49.

Kharaziha, P., Hellström, P. M., Noorinayer, B., Farzaneh, F., Aghajani, K., Jafari, F., Telkabadi, M., Atashi, A., Honardoost, M., Zali, M. R., and Soleimani, M. (2009). Improvement of liver function in liver cirrhosis patients after autologous mesenchymal stem cell injection: a phase I-II clinical trial. Eur. J. Gastroenterol. Hepatol. 21, 1199-1205.

Kinnaird, T., Stabile, E., Burnett, M. S., Lee, C. W., Barr, S., Fuchs, S., Epstein, S. E. (2004). Marrow-derived stromal cells express genes encoding a broad spectrum of arteriogenic cytokines and promote in vitro and in vivo arteriogenesis through paracrine mechanisms. Circ. Res. 94, 678-685.

Klyushnenkova, E., Mosca, J. D., Zernetkina, V., Majumdar, M. K., Beggs, K. J., Simonetti, D. W., Deans, R. J., and McIntosh, K. R. (2005). T cell responses to allogeneic human mesenchymal stem cells: immunogenicity, tolerance, and suppression. J. Biomed. Sci. 12, 47-57.

Kode, J. A., Mukherjee, S., Joglekar, M. V., and Hardikar, A. A. (2009). Mesenchymal stem cells: immunobiology and role in immunomodulation and tissue regeneration. Cytotherapy 11, 377-391.

Koenig, S., Aurich, H., Schneider, C., Krause, P., Haftendorn, R., Becker, H., and Christ, B. (2007). Zonal expression of hepatocytic marker enzymes during liver repopulation. Histochem. Cell Biol. 128, 105-114.

Kofman, A. V., Morgan, G., Kirschenbaum, A., Osbeck, J., Hussain, M., Swenson, S., and Theise, N. D. (2005). Dose- and time-dependent oval cell reaction in acetaminopheninduced murine liver injury. Hepatology 41, 1252-1261.

Koniaris, L. G., McKillop, I. H., Schwartz, S. I., and Zimmers, T. A. (2003). Liver regeneration. J. Am. Coll. Surg. 197, 634-659.

Krampera, M., Cosmi, L., Angeli, R. Pasini, A., Liotta, F., Andreini A., Santarlasci, V., Mazzinghi, B., Pizzolo, G., Vinante, F., Romagnani, P., Maggi, E., Romagnani, S., and Annunziato, F. (2006). Role for interferon-gamma in the immunomodulatory activity of human bone marrow mesenchymal stem cells. Stem Cells 24, 386-398.

Krampera, M., Sartoris, S., Liotta, F., Pasini, A., Angeli, R., Cosmi, L., Andreini, A., Mosna, F., Bonetti, B. Rebellato, E., Testi, M. G., Frosali, F., Pizzolo, G., Tridente, G., Maggi, E., Romagnani, S., and Annunziato, F. (2007). Immune regulation by mesenchymal stem cells derived from adult spleen and thymus. Stem Cells Dev. 16, 797-810.

Kubota, K., Soeda, J., Misawa, R., Mihara, M., Miwa, S., Ise, H., Takahashi, M., and Miyagawa, S. (2008). Bone marrow-derived cells fuse with hepatic oval cells but are not involved in hepatic tumorigenesis in the choline-deficient ethioninesupplemented diet rat model. Carcinogenesis 29, 448-454.

Kusano, M., and Mito, M. (1982). Observations on the fine structure of long-survived isolated hepatocytes inoculated into rat spleen. Gastroenterology 82, 616-628.

Lagasse, E., Connors, H., Al-Dhalimy, M., Reitsma, M., Dohse, M., Osborne, L., Wang, X., Finegold, M., Weissman, I. L., and Grompe, M. (2000). Purified hematopoietic stem cells can differentiate into hepatocytes in vivo. Nat. Med. 6 , 1229-1234.

Lange, C., Bassler, P., Lioznov, M. V., Bruns, H., Kluth, D., Zander, A. R. and Fiegel, H. C. (2005). Hepatocytic gene expression in cultured rat mesenchymal stem cells. Transplant. Proc. 37, 276-279. 
Le Blanc, K., and Ringden, O. (2005). Immunobiology of human mesenchymal stem cells and future use in hematopoietic stem cell transplantation. Biol. Blood Marrow Transplant. 11, 321-334.

Le Blanc, K., Tammik, C., Rosendahl, K., Zetterberg, E., and Ringdén, O. (2003). HLA expression and immunologic properties of differentiated and undifferentiated mesenchymal stem cells. Exp. Hematol. 31, 890-896.

Lee, K. D., Kuo, T. K., Whang-Peng, J., Chung, Y. F., Lin, C. T., Chou, S. H., Chen, J. R., Chen, Y. P., and Lee, O. K. (2004a). In vitro hepatic differentiation of human mesenchymal stem cells. Hepatology 40, 1275-1284.

Lee, S.-W., Wang, X., Chowdhury, N. R., and Chowdhury, J. R. (2004b). Hepatocyte transplantation: state of the art and strategies for overcoming existing hurdles. Ann. Hepatol. 3 , 48-53.

Li, J., Zhang, L., Xin, J., Jiang, L., Li, J., Zhang, T., Jin, L., Li, J., Zhou, P., Hao, S., Cao, H., and Li, L. (2012). Immediate intraportal transplantation of human bone marrow mesenchymal stem cells prevents death from fulminant hepatic failure in pigs. Hepatology. doi: 10.1002/hep.25722. [Epub ahead of print].

Lysy, P. A., Campard, D., Smets, F., Malaise, J., Mourad, M., Najimi, M., and Sokal, E. M. (2008). Persistence of a chimerical phenotype after hepatocyte differentiation of human bone marrow mesenchymal stem cells. Cell Prolif. 41, 36-58.

Mao, F., Xu, W. R., Qian, H., Zhu, W., Yan, Y. M., Shao, Q. X., and HX, X. (2010). Immunosuppressive effects of mesenchymal stem cells in collagen-induced mouse arthritis. Inflamm. Res. 59, 219-225.

Martínez-Climent, J. A., Andreu, E. J., and Prosper, F. (2006). Somatic stem cells and the origin of cancer. Clin. Transl. Oncol. 8, 647-663.

Meisel, R., Zibert, A., Laryea, M., Gobel, U., Daubener, W., and Dilloo, D. (2004). Human bone marrow stromal cells inhibit allogeneic T-cell responses by indoleamine 2,3dioxygenase-mediated tryptophan degradation. Blood 103, 4619-4621.

Michalopoulos, G. K. (2007). Liver regeneration. J. Cell. Physiol. 213, 286-300.

Michalopoulos, G. K. (2010). Liver regeneration after partial hepatectomy: critical analysis of mechanistic dilemmas. Am. J. Pathol. 176, 2-13.

Michalopoulos, G. K., Barua, L., and Bowen, W. C. (2005). Transdifferentiation of rat hepatocytes into biliary cells after bile duct ligation and toxic biliary injury. Hepatology 41, 535-544.

Mishra, P. J., Mishra, P. J., Glod, J. W., and Banerjee, D. (2009). Mesenchymal stem cells: flip side of the coin. Cancer Res. 69, 1255-1258.

Munn, D. H., Zhou, M., Attwood, J. T., Bondarev, I., Conway, S. J., Marshall, B., Brown, C., and Mellor, A. L. (1998). Prevention of allogeneic fetal rejection by tryptophan catabolism. Science 281, 1191-1193.

Muraca, M. (2011). Evolving concepts in cell therapy of liver disease and current clinical perspectives. Dig. Liver. Dis. 43, 180-187.

Muraca, M., Gerunda, G., Neri, D., Vilei, M. T., Granato, A., Feltracco, P., Meroni, M., Giron, G., and Burlina, A. B. (2002). Hepatocyte transplantation as a treatment for glycogen storage disease type 1a. Lancet 359, 317-318.

Najimi, M., Khuu, D. N., Lysy, P. A., Jazouli, N., Abarca, J., Sempoux, C., and Sokal, E. M. (2007). Adultderived human liver mesenchymallike cells as a potential progenitor reservoir of hepatocytes? Cell Transplant. 16, 717-728.

Nasef, A., Mathieu, N., Chapel, A., Frick, J., François, S., Mazurier, C., Boutarfa, A., Bouchet, S., Gorin, N. C., Thierry, D., and Fouillard, L. (2007). Immunosuppressive effects of mesenchymal stem cells: involvement of HLA-G. Transplantation 84, 231-237.

Nauta, A. J., and Fibbe, W. E. (2007). Immunomodulatory properties of mesenchymal stromal cells. Blood 110, 3499-3506.

Nauta, A. J., Kruisselbrink, A. B. Lurvink, E., Willemze, R., and Fibbe, W. E. (2006). Mesenchymal stem cells inhibit generation and function of both CD34+-derived and monocyte-derived dendritic cells. J. Immunol. 177, 2080-2087.

Nejak-Bowen, K. N., and Monga, S. P. S. (2011). Beta-catenin signaling, liver regeneration and hepatocellular cancer: Sorting the good from the bad. Semin. Cancer Biol. 21, 44-58.

Newman, R. E., Yoo, D., LeRoux, M. A., and Danilkovitch-Miagkova, A. (2009). Treatment of inflammatory diseases with mesenchymal stem cells. Inflamm. Allergy Drug Targets 8, 110-123.

Newsome, P. N., Johannessen, I., Boyle, S., Dalakas, E., McAulay, K. A., Samuel, K., Rae, F., Forrester, L., Turner, M. L., Hayes, P. C., Harrison, D. J., Bickmore, W. A., and Plevris, J. N. (2003). Human cord blood-derived cells can differentiate into hepatocytes in the mouse liver with no evidence of cellular fusion. Gastroenterology 124, 1891-1900.

Noel, D., Djouad, F., Bouffi, C., Mrugala, D., and Jorgensen, C. (2007). Multipotent mesenchymal stromal cells and immune tolerance. Leuk. Lymphoma 48, 1283-1289.

Oertel, M., and Shafritz, D. A. (2008). Stem cells, cell transplantation and liver repopulation. Biochim. Biophys. Acta 1782, 61-74.

Okita, K., and Yamanaka, S. (2011). Induced pluripotent stem cells: opportunities and challenges. Philos. Trans. R. Soc. Lond. B Biol. Sci. 366, 2198-2207.

Ostapowicz, G., and Lee, W. M. (2000). Acute hepatic failure: a western perspective. J. Gastroenterol. Hepatol. $15,480-488$.

Oyagi, S., Hirose, M., Kojima, M., Okuyama, M., Kawase, M., Nakamura, T., Ohgushi, H., and Yagi, K. (2006). Therapeutic effect of transplanting HGF-treated bone marrow mesenchymal cells into $\mathrm{CCl} 4$ injured rats. J. Hepatol. 44, 742-748.

O'Grady, J. G. (2005). Acute liver failure. Postgrad. Med. J. 81, 148-154.

Pan, Q., Fouraschen, S. M. G., Kaya, F. S. F. A., Verstegen, M. M., Pescatori, M., Stubbs, A. P., van IJcken, W., van der Sloot, A., Smits, R., Kwekkeboom, J., Metselaar, H. J., Kazemier, G., de Jonge, J., Tilanus, H. W., Wagemaker, G., Janssen, H. L., and van der Laan, L. J. (2011). Mobilization of hepatic mesenchymal stem cells from human liver grafts. Liver Transpl. 17, 596-609.

Parekkadan, B., van Poll, D., Suganuma, K., Carter, E. A., Berthiaume, F., Tilles, A. W., and Yarmush, M. L. (2007). Mesenchymal stem cellderived molecules reverse fulminant hepatic failure. PLoS ONE. 2, e941. doi:10.1371/journal.pone.0000941

Pereira, R. F., Halford, K. W., O’Hara, M. D., Leeper, D. B., Sokolov, B. P., Pollard, M. D., Bagasra, O., and Prockop, D. J. (1995). Cultured adherent cells from marrow can serve as longlasting precursor cells for bone, cartilage, and lung in irradiated mice. Proc. Natl. Acad. Sci. U.S.A. 92, 4857-4861.

Petersen, B. E., Bowen, W. C., Patrene, K. D., Mars, W. M., Sullivan, A. K., Murase, N., Boggs, S. S., Greenberger, J. S., and Goff, J. P. (1999). Bone marrow as a potential source of hepatic oval cells. Science 284, 1168-1170.

Pittenger, M. F., Mackay, A. M., Beck, S. C., Jaiswal, R. K., Douglas, R., Mosca, J. D., Moorman, M. A., Simonetti,
D. W., Craig, S., and Marshak, D. R. (1999). Multilineage potential of adult human mesenchymal stem cells. Science 284, 143-147.

Polyak, K., and Hahn, W. C. (2006). Roots and stems: stem cells in cancer. Nat. Med. 12, 296-300.

Puppi, J., Strom, S. C., Hughes, R. D., Bansal, S., Castell, J. V., Dagher, I., Ellis, E. C., Nowak, G., Ericzon, B. G., Fox, I. J., Gómez-Lechón, M. J., Guha, C., Gupta, S., Mitry, R. R., Ohashi, K., Ott, M., Reid, L. M., RoyChowdhury, J., Sokal, E., Weber, A., and Dhawan, A. (2011). Improving the techniques for human hepatocyte transplantation: report from a consensus meeting in London. Cell Transplant. 21, 1-10.

Rahman, T., and Hodgson, H. (2001). Clinical management of acute hepatic failure. Intensive Care Med. 27, 467-476.

Rajvanshi, P., Fabrega, A., Bhargava, K. K., Kerr, A., Pollak, R., Blanchard, J., Palestro, C. J., and Gupta, S. (1999). Rapid clearance of transplanted hepatocytes from pulmonary capillaries in rats indicates a wide safety margin of liver repopulation and the potential of using surrogate albumin particles for safety analysis. J. Hepatol. 30, 299-310.

Ramasamy, R., Fazekasova, H., Lam, E. W., Soeiro, I., Lombardi, G., and Dazzi, F. (2007). Mesenchymal stem cells inhibit dendritic cell differentiation and function by preventing entry into the cell cycle. Transplantation 83, 71-76.

Renner, P., Eggenhofer, E., Rosenauer, A., Popp, F. C., Steinmann, J. F., Slowik, P., Geissler, E. K., Piso, P., Schlitt, H. J., and Dahlke, M. H. (2009). Mesenchymal stem cells require a sufficient, ongoing immune response to exert their immunosuppressive function. Transplant. Proc. 41, 2607-2611.

Riehle, K. J., Dan, Y. Y., Campbell, J. S., and Fausto, N. (2011). New concepts in liver regeneration. J. Gastroenterol. Hepatol. 26, 203-212.

Roskams, T., Katoonizadeh, A., and Komuta, M. (2010). Hepatic progenitor cells: an update. Clin. Liver. Dis. 14, 705-718.

Roskams, T. A., Theise, N. D., Balabaud, C., Bhagat, G., Bhathal, P. S., BioulacSage, P., Brunt, E. M., Crawford, J. M., Crosby, H. A., Desmet, V., Finegold, M. J., Geller, S. A., Gouw, A. S., Hytiroglou, P., Knisely, A. S., Kojiro, M., Lefkowitch, J. H., Nakanuma, Y., Olynyk, J. K., Park, Y. N., Portmann, B., Saxena, R., Scheuer, P. J., Strain, 
A. J., Thung, S. N., Wanless, I. R., and West, A. B. (2004). Nomenclature of the finer branches of the biliary tree: canals, ductules, and ductular reactions in human livers. Hepatology 39 , 1739-1745.

Rountree, C. B., Mishra, L., and Willenbring, H. (2012). Stem cells in liver diseases and cancer: recent advances on the path to new therapies. Hepatology 55, 298-306.

Ryan, J. M., Barry, F., Murphy, J. M., and Mahon, B. P. (2007). Interferon-gamma does not break, but promotes the immunosuppressive capacity of adult human mesenchymal stem cells. Clin. Exp. Immunol. 149, 353-363.

Santoni-Rugiu, E., Jelnes, P., Thorgeirsson, S. S., and Bisgaard, $\mathrm{H}$. C. (2005). Progenitor cells in liver regeneration: molecular responses controlling their activation and expansion. APMIS 113, 876-902.

Sato, Y., Araki, H., Kato, J., Nakamura, K., Kawano, Y., Kobune, M., Sato, T., Miyanishi, K., Takayama, T., Takahashi, M., Takimoto, R., Iyama, S., Matsunaga, T., Ohtani, S., Matsuura, A., Hamada, H., and Niitsu, Y. (2005). Human mesenchymal stem cells xenografted directly to rat liver are differentiated into human hepatocytes without fusion. Blood 106, 756-763.

Schneider, A., Attaran, M., Gratz, K. F., Bleck, J. S., Winkler, M., Manns, M. P., and Ott, M. (2003). Intraportal infusion of 99mtechnetium-macroaggregrated albumin particles and hepatocytes in rabbits: assessment of shunting and portal hemodynamic changes. Transplantation 75 , 296-302.

Schwartz, R. E., Reyes, M., Koodie, L., Jiang, Y., Blackstad, M., Lund, T., Lenvik, T., Johnson, S., Hu, W. S., and Verfaillie, C. M. (2002). Multipotent adult progenitor cells from bone marrow differentiate into functional hepatocytelike cells. J. Clin. Invest. 109, 1291-1302.

Sell, S. (2001). Heterogeneity and plasticity of hepatocyte lineage cells. Hepatology 33, 738-750.

Seo, M. J., Suh, S. Y., Bae, Y. C., and Jung, J. S. (2005). Differentiation of human adipose stromal cells into hepatic lineage in vitro and in vivo. Biochem. Biophys. Res. Commun. $328,258-264$.

Sgodda, M., Aurich, H., Kleist, S., Aurich, I., Konig, S., Dollinger, M. M., Fleig, W. E., and Christ, B. (2007). Hepatocyte differentiation of mesenchymal stem cells from rat peritoneal adipose tissue in vitro and in vivo. Exp. Cell. Res. 313, 2875-2886.

Shafritz, D. A., and Oertel, M. (2011) Model systems and experimental conditions that lead to effective repopulation of the liver by transplanted cells. Int. J. Biochem. Cell. Biol. 43, 198-213.

Shi, X. L., Gu, J. Y., Han, B., Xu, H. Y., Fang, L., and Ding, Y. T. (2010). Magnetically labeled mesenchymal stem cells after autologous transplantation into acutely injured liver. World J. Gastroenterol. 16, 3674-3679.

Siegel, G., Schäfer, R., and Dazzi, F. (2009). The immunosuppressive properties of mesenchymal stem cells. Transplantation 87, S45-S49.

Sotiropoulou, P. A., Perez, S. A., Gritzapis, A. D., Baxevanis, C. N., and Papamichail, M. (2006). Interactions between human mesenchymal stem cells and natural killer cells. Stem Cells 24, 74-85.

Spaggiari, G. M., Capobianco, A., Becchetti, S., Mingari, M. C., and Moretta, L. (2006). Mesenchymal stem cell-natural killer cell interactions: evidence that activated NK cells are capable of killing MSCs, whereas MSCs can inhibit IL-2induced NK-cell proliferation. Blood 107, 1484-1490.

Spee, B., Carpino, G., Schotanus, B. A., Katoonizadeh, A., Borght, S. V., Gaudio, E., and Roskams, T. (2010). Characterisation of the liver progenitor cell niche in liver diseases: potential involvement of wnt and notch signalling. Gut 59, 247-257.

Stagg, J., and Galipeau, J. (2007). Immune plasticity of bone marrowderived mesenchymal stromal cells. Handb. Exp. Pharmacol. 180, 45-66.

Steiner, J. W., Perz, Z. M., and Taichman, L. B. (1966). Cell population dynamics in the liver: a review of quantitative morphological techniques applied to the study of physiological and pathological growth. Exp. Mol. Pathol. 5, 146-181.

Studeny, M., Marini, F. C., Dembinski, J. L., Zompetta, C., CabreiraHansen, M., Bekele, B. N., Champlin, R. E., and Andreeff, M. (2004). Mesenchymal stem cells: potential precursors for tumor stroma and targeted-delivery vehicles for anticancer agents. J. Natl. Cancer Inst. 96, 1593-1603.

Stutchfield, B. M., Forbes, S. J., and Wigmore, S. J. (2010). Prospects for stem cell transplantation in the treatment of hepatic disease. Liver Transpl. 16, 827-836.
Takahashi, K., and Yamanaka, S. (2006). Induction of pluripotent stem cells from mouse embryonic and adult fibroblast cultures by defined factors. Cell 126, 663-676.

Takayama, K., Inamura, M., Kawabata, K., Katayama, K., Higuchi, M. Tashiro, K., Nonaka, A., Sakurai, F. Hayakawa, T., Furue, M. K., and Mizuguchi, H. (2012). Efficient generation of functional hepatocytes from human embryonic stem cells and induced pluripotent stem cells by HNF4[alpha] transduction. Mol. Ther. 20, 127-137.

Taléns-Visconti, R., Bonora, A., Jover, R., Mirabet, V., Carbonell, F., Castell, J. V., and Gómez-Lechón, M. J. (2006). Hepatogenic differentiation of human mesenchymal stem cells from adipose tissue in comparison with bone marrow mesenchymal stem cells. World J. Gastroenterol. 12 , 5834-5845.

Theise, N. D., Badve, S., Saxena, R. Henegariu, O., Sell, S., Crawford, J. M., and Krause, D. S. (2000). Derivation of hepatocytes from bone marrow cells in mice after radiationinduced myeloablation. Hepatology $31,235-240$.

Tsai, P.-C., Fu, T.-W., Chen, Y.-M. A., Ko, T.-L., Chen, T.-H., Shih, Y.-H., Hung, S.-C., and Fu, Y. S. (2009). The therapeutic potential of human umbilical mesenchymal stem cells from Wharton's jelly in the treatment of rat liver fibrosis. Liver Transpl. 15, 484-495.

Turner, R., Lozoya, O., Wang, Y., Cardinale, V., Gaudio, E., Alpini, G., Mendel, G., Wauthier, E., Barbier, C. Alvaro, D., and Reid, L. M. (2011) Human hepatic stem cell and maturational liver lineage biology. Hepatology 53, 1035-1045.

Van Den Heuvel, M. C., Slooff, M. J. H., Visser, L., Muller, M., De Jong, K. P., Poppema, S., and Gouw, A. S. H. (2001). Expression of anti-OV6 antibody and anti-N-CAM antibody along the biliary line of normal and diseased human livers. Hepatology 33, 1387-1393.

van Poll, D., Parekkadan, B., Cho, C. H., Berthiaume, F., Nahmias, Y., Tilles, A. W., and Yarmush, M. L. (2008). Mesenchymal stem cellderived molecules directly modulate hepatocellular death and regeneration in vitro and in vivo. Hepatology 47, 1634-1643.

Vassilopoulos, G. P., Wang, R., and Russell, D. W. (2003). Transplanted bone marrow regenerates liver by cell fusion. Nature 422, 901-904.

Wang, P. P., Wang, J. H., Yan, Z. P., Hu, M. Y., Lau, G. K., Fan, S.
T., and Luk, J. M. (2004). Expression of hepatocyte-like phenotypes in bone marrow stromal cells after HGF induction. Biochem. Biophys. Res. Commun. 320, 712-716.

Wang, X., Ge, S., McNamara, G., Hao, Q.-L., Crooks, G. M., and Nolta, J. A. (2003a). Albumin-expressing hepatocyte-like cells develop in the livers of immune-deficient mice that received transplants of highly purified human hematopoietic stem cells. Blood 101, 4201-4208.

Wang, X., Willenbring, H., Akkari, Y., Torimaru, Y., Foster, M., Al-Dhalimy, M., Lagasse, E., Finegold, M., Olson, S., and Grompe, M. (2003b). Cell fusion is the principal source of bone-marrow-derived hepatocytes. Nature 422, 897-901.

Weber, A., Groyer-Picard, M.-T., Franco, D., and Dagher, I. (2009). Hepatocyte transplantation in animal models. Liver Transpl. 15, 7-14.

Wu, X.-Z., and Yu, X.-H. (2007). Bone marrow cells: the source of hepatocellular carcinoma? Med. Hypotheses $69,36-42$.

Wu, X. Z. (2008). Origin of cancer stem cells: the role of self-renewal and differentiation. Ann. Surg. Oncol. 15, 407-414.

Yagi, H., Tafaleng, E., Nagaya, M., Hansel, M. C., Strom, S. C., Fox, I. J., and Soto-Gutierrez, A. (2009). Embryonic and induced pluripotent stem cells as a model for liver disease. Crit. Rev. Biomed. Eng. 37, 377-398.

Yanez, R., Lamana, M. L., GarciaCastro, J., Colmenero, I., Ramirez, M., Bueren, J. A. (2006). Adipose tissue-derived mesenchymal stem cells have in vivo immunosuppressive properties applicable for the control of the graftversus-host disease. Stem Cells 24 2582-2591.

Zagoura, D. S., Roubelakis, M. G., Bitsika, V., Trohatou, O., Pappa, K. I., Kapelouzou, A., Antsaklis, A., and Anagnou, N. P. (2012). Therapeutic potential of a distinct population of human amniotic fluid mesenchymal stem cells and their secreted molecules in mice with acute hepatic failure. Gut 61, 894-906.

Zhang, Z., Lin, H., Shi, M., Xu, R. Fu, J., Lv, J., Chen, L., Lv, S., Li, Y., Yu, S., Geng, H., Jin, L., Lau, G. K., and Wang, F. S. (2012). Human umbilical cord mesenchymal stem cells improve liver function and ascites in decompensated liver cirrhosis patients. J. Gastroenterol. Hepatol. 27, 112-120. 
Zheng, J. F., and Liang, L. J. (2008). Transplanted bone marrow stromal cells are not cellular origin of hepatocellular carcinomas in a mouse model of carcinogenesis. World J. Gastroenterol. 14, 3015-3020.

Zheng, Z. H., Li, X. Y., Ding, J., Jia, J. F., and Zhu, P. (2008). Allogeneic mesenchymal stem cell and mesenchymal stem cell-differentiated chondrocyte suppress the responses of type II collagen-reactive $\mathrm{T}$ cells in rheumatoid arthritis. Rheumatology $47,22-30$.
Zhu, W., Xu, W., Jiang, R., Qian, H., Chen, M., Hu, J., Cao, W., Han, C., and Chen, Y. (2006). Mesenchymal stem cells derived from bone marrow favor tumor cell growth in vivo. Exp. Mol. Pathol. 80, 267-274.

Zischek, C., Niess, H., Ischenko, I., Conrad, C., Huss, R., Jauch, K. W., Nelson, P. J., and Bruns, C. (2009). Targeting tumor stroma using engineered mesenchymal stem cells reduces the growth of pancreatic carcinoma. Ann. Surg. Oncol. 250, 747-753.
Conflict of Interest Statement: The authors declare that the research was conducted in the absence of any commercial or financial relationships that could be construed as a potential conflict of interest.

Received: 26 March 2012; accepted: 04 June 2012; published online: 22 June 2012.

Citation: Christ $B$ and Stock $P$ (2012) Mesenchymal stem cell-derived hepatocytes for functional liver replacement. Front. Immun. 3:168. doi: 10.3389/fimmu.2012.00168

This article was submitted to Frontiers in Alloimmunity and Transplantation, a specialty of Frontiers in Immunology.

Copyright (C) 2012 Christ and Stock. This is an open-access article distributed under the terms of the Creative Commons Attribution Non Commercial License, which permits non-commercial use, distribution, and reproduction in other forums, provided the original authors and source are credited. 